\title{
Hvad ville Jesus spise? Bibelreception i kogebøger
}

\author{
ANNE KATRINE DE HEMMER GUDME
}

\begin{abstract}
ENGLISH ABSTRACT: This article examines the reception of the Bible in Bible cookbooks. Bible cookbooks can be divided into two groups: 1) Bible cookbooks that use recipes and food as a medium to disseminate Bible texts and 'Bibelkunde', and 2) Bible cookbooks that use the Bible as an authoritative guide when it comes to deciding what and how to eat. In the article, I give examples of both types of Bible cookbooks and I give a brief introduction to the biblical texts that have attracted the most attention among Bible cookbook authors. The analysis focuses on how the Bible cookbook authors use and interpret the Biblical text and considers the relationship between Bible cookbooks and rewritten Bible.
\end{abstract}

DANSK RESUME: Denne artikel undersøger bibelreception i kogebogslitteraturen, nærmere bestemt $i$ bibelkogebøger. Der findes overordnet set to slags bibelkogebøger: (1) 'den formidlende bibelkogebog', hvis primære interesse det er at populærformidle bibeltekster og bibelhistorier, og (2) 'den etiske bibelkogebog', der anser Bibelen for at kunne bruges som vejledning til, hvad og hvordan man bør spise. I artiklen vil jeg give eksempler på de to typer af bibelkogebøger, formidlingskogebogen og den etiske kogebog, samt en kort introduktion til de bibelske tekster, der har tiltrukket sig mest opmærksomhed inden for bibelkogebogsgenren. Analysen af bibelkogebøgerne fokuserer på forfatternes bibelbrug og på bibelkogebogens slægtskab med genren bibelske genskrivninger.

KEYWORDS: Food; Cookbooks; Reception of the Bible; Rewritten Bible; Ethics of Eating; Hebrew Bible

\section{Indledning}

Denne artikel undersøger bibelreception i kogebogslitteraturen, nærmere bestemt i bibelkogebøger. En bibelkogebog er en kogebog, der tager udgangspunkt i Bibelen, og som henter inspiration eller autoritet i de bibelske tekster til de opskrifter den indeholder. I grove træk findes der to slags bibelkogebøger: (1) bibelkogebøger, hvis primære intention er at formidle bibeltekster og bibelhistorier, hvor bibelkogebogen 
bliver et middel til et formidlingsmål, og (2) bibelkogebøger, der forsøger at komme med et bud på, hvad den 'rigtige' diæt og den 'rigtige' måde at spise på er ifølge Bibelen, hvor bibelkogebogen bliver et middel til at leve (og spise) i overensstemmelse med de bibelske tekster, det jeg kalder 'den etiske kogebog'. Der er forskel på, hvor stor autoritet forfatterne til de etiske kogebøger tillægger bibelteksten; men fælles for dem er, at de anser Bibelen for at kunne bruges som vejledning til, hvad og hvordan man bør spise.

I det følgende vil jeg lægge ud med en præsentation af formidlingskogebogen og en overvejelse over dens placering imellem to litterære genrer, genskrevet bibel og kendis-kogebøger. Herefter vil jeg forlade kogebøgerne for en stund for at give en kort introduktion til de bibelske tekster, der har tiltrukket sig mest opmærksomhed blandt forfatterne til det, jeg kalder den etiske kogebog. Dernæst vil jeg give et par eksempler på netop etiske bibelkogebøger og hvordan de bruger bibelteksten. Bibelkogebøger er i høj grad et engelsksproget fænomen, og der er kun udkommet ganske få bibelkogebøger på dansk. En af de få danske udgivelser er Poul Joachim Stender og Susanne Engelstoft Rasmussens Præsten \& Kogejomfruen (2003). Stender og Rasmussens bibelkogebog er både formidlende og etisk, og med en kort præsentation af den vil jeg runde min undersøgelse af bibelkogebøger som bibelreception af.

\section{Linser, fedekalv og pastasalat: Den formidlende bibelkogebog}

Den formidlende bibelkogebog er et forskelligartet fænomen; men det, der binder denne kategori sammen, er, at der er tale om kogebøger, der er bygget op omkring eller inspireret af bibelske tekster og fortællinger. Den formidlende bibelkogebog bruger opskrifter og madlavning som et medium til at formidle Bibelen, ligesom Bibelens tekstunivers ofte er den tematiske og kulturelle ramme, som kogebogen er skrevet ind i. Den formidlende bibelkogebog kan have karakter af et bibelatlas med opskrifter, som det er tilfældet med Miriam Feinberg Vamoshs Food at the Time of the Bible: From Adam's Apple to the Last Supper (2004), hvor et begrænset antal egentlige opskrifter (44) er ledsaget af et væld af information om oldtidens Palæstinas geografi, økologi, arkæologi og køkken, og naturligvis med hyppige referencer til mad- og måltidsrelaterede bibeltekster. Men den formidlende bibelkogebog kan også være bygget op som en klassisk kogebog, hvor opskrifterne er i fokus, og hvor bibelreferencerne er begrænset til at danne rammen for bogens temakøkken, i dette tilfælde middelhavskøkkenet. Det kan man se et eksempel på i Kitty Morses A Biblical Feast: Ancient Mediterranean Flavors for Today's Table (2009), som i bund og grund er en typisk moderne kogebog med kortfattede og lettilgængelige opskrifter, ledsaget af smukke og sensuelle nærbilleder af de retter, der er at finde i bogen, men hvor hver opskrift indledes med et bibelcitat. Sammenhængen mellem bibelcitat og opskrift er til tider temmelig løs, som i opskriften på dild-agurker med oliven og gedeost (Morse 2009, 38), hvor bibelcitatet stammer fra Es 1,8, der beskriver det udsatte og svækkede Jerusalem 
som et forladt skur i agurkemarken. ${ }^{1}$ Andre gange hænger det lidt bedre sammen, som i opskriften på grillede vagtler, der indledes med det mirakuløse vagteltræk i 2 Mos 16,13 (Morse 2009, 54), eller opskriften på en suppe af oksebouillon med linser, perlebyg og sennepsblade, der indledes med et citat fra 1 Mos 25,34, hvor Esau sælger sin førstefødselsret til sin lillebror, Jakob, for en portion linser (Morse 2009, 49).

Størstedelen af de formidlende bibelkogebøger tager udgangspunkt i bibelske fortællinger om måltider, og bruger dem som baggrund for en eller flere opskrifter. Det kan man fx finde eksempler på i Cooking with the Bible: Recipes for Biblical Meals (Chiffolo og Hesse 2006), Eating the Bible: Over 50 Delicious Recipes to Feed your Body and Nourish your Soul (Rossner 2013) og Tasty Bible Stories: A Menu of Tales E Matching Recipes (Lehmann-Wilzig 2003). Her genoptrykkes eller genfortælles udvalgte bibelfortællinger som optakt til opskrifter på mere eller mindre 'bibelske' måltider. Generelt lægges der vægt på den gode fortælling og på bibeltemaet, og i langt mindre grad på historiske ingredienser og tilberedningsmetoder. Således skal man ikke blive alt for overrasket, hvis man støder på en opskrift på sprøde kartoffelreder (Rossner 2013, 225) eller på pastasalat med tun (Lehmann-Wilzig 2003, 27) i en formidlende bibelkogebog. Hverken pasta eller kartofler var kendte ingredienser i middelhavsområdet $\mathrm{i}$ oldtiden, men kartoffelrederne er inspireret af Femte Mosebogs instruks om den korrekte måde at plyndre en fuglerede på (22,6-7), ligesom tunen i pastasalaten er hentet i Jonas' Bog, hvor den vrangvillige profet bliver slugt af en "stor fisk" (Jon 2,1), og store fisk i Middelhavet kunne såmænd godt være tun. Kogebøger med historiske opskrifter fra det gamle Rom, fra Middelalderen, Renæssancen m.m. er et efterhånden velkendt fænomen i diverse boghandler og museumsbutikker, men den formidlende bibelkogebog hører ikke til i denne genre. Bibelske fortællinger, temaer og til tider ingredienser slår temaet an, men størstedelen af opskrifterne er tilpasset moderne smag, indkøbsmuligheder og tilberedningsmetoder.

I 2005 udgav Det Danske Bibelselskab et lille hæfte i anledning af kulturnatten. Hæftet hedder Smag på Bibelen: Fra Adams æble til den sidste nadver, og det indeholder femten enkle opskrifter, der hver tager udgangspunkt i en bibeltekst eller bibelfortælling. Som undertitlen antyder, er Smag på Bibelen kraftigt inspireret af bibelkogebogen Food at the Time of the Bible: From Adam's Apple to the Last Supper (Vamosh 2004), som jeg nævnte ovenfor, og tolv af de i alt femten opskrifter i hæftet synes da også at stamme derfra, selvom der ikke henvises til bogen.

\subsection{Jakobs linser}

Der er stor variation blandt de formidlende bibelkogebøger, de findes til både børn og voksne, til bibelkyndige og bibelfremmede, og de går mere eller mindre op i histo-

1 Den hebraiske glose miqšāh oversættes i DO-1992 med "melonmark" og i DO-1931 med "græskarmark", men gengives oftest på engelsk med "agurk" (cucumber). Her er de danske oversættelser bedst, i og med at den plante, der henvises til med det hebraiske miqšāh (Es 1,8) og qišuijm (4 Mos $11,5)$, formodentlig er en type melon, Cucumis melo, der er nært beslægtet med den velkendte cantaloupe eller netmelon, og kun fjernt beslægtet med vores almindelige, grønne og aflange agurk, $\mathrm{Cu}$ cumis sativus (Musselman 2011, 44-45). 
risk korrekthed, selvom de, som nævnt ovenfor, aldrig bliver decideret historiske kogebøger. Der er dog også nogle fællestræk, der kan hjælpe os til at sammenfatte den formidlende bibelkogebog som litterært fænomen.

For det første indeholder formidlende bibelkogebøger som oftest langt flere fortællinger fra Det Gamle Testamente end fra Det Nye Testamente. Det skyldes det helt enkle forhold, at der er langt flere madrelaterede tekster i Det Gamle end i Det Nye Testamente - ja, der er i det hele taget bare flere tekster i Det Gamle Testamente.

For det andet er den formidlende bibelkogebog præget af den paradoksale blanding af overflod og kortfattethed, der gør sig gældende i bibelske tekster om mad. Der er talrige referencer til mad og måltider og råvarer i Bibelen, men der er fortvivlende få konkrete oplysninger om tilberedningsmetoder, sammensætning af retter og ingredienser m.m. Der er især to bibelfortællinger, der går igen i de formidlende bibelkogebøger, og det er historien om Abraham og Saras beværtning af tre guddommelige gæster i 1 Mos 18 og Jakobs linseret i 1 Mos 25, som jeg kort berørte ovenfor. Jakobs linser illustrerer fint kortfattetheden i Bibelens oplysninger om madlavning:

Da drengene voksede til, blev Esau en dygtig jæger, der holdt til på steppen, mens Jakob var et ordentligt menneske, der boede i telt. Isak elskede Esau, fordi han holdt af vildt, men Rebekka elskede Jakob.

Engang da Jakob havde kogt en ret mad, og Esau kom udmattet hjem, sagde Esau til Jakob: "Giv mig hurtigt noget af det røde at spise, det røde du har dér, for jeg er udmattet." Derfor kaldes han Edom. Men Jakob svarede: "Ikke før du sælger mig din førstefødselsret.” Da sagde Esau: “Jeg er lige ved at dø! Hvad skal jeg med min førstefødselsret?" "Sværg på det," sagde Jakob, og det gjorde Esau; han solgte sin førstefødselsret til Jakob. Så gav Jakob ham brød og en portion linser; Esau spiste og drak og gik derefter sin vej. Og sådan viste Esau ringeagt for sin førstefødselsret (1 Mos 25,27-34).

Der er megen information i denne lille fortælling. Vi hører om forskellene på de to brødre; Esau er fars yndling, den mandige jæger, næsten en vildmand, som er grov og ubesindig, styret af sin sult og sine impulser. Heroverfor er Jakob "et ordentligt menneske", mors dreng, der bliver hjemme og vogter får, og ligesom sin mor er han snu og udspekuleret. Denne modsætning mellem brødrene, vildmanden og mors dreng, dukker op igen i 1 Mos 27 i fortællingen om endnu et skæbnesvangert måltid, hvor Rebekka lader sin yndlingssøn, Jakob, give sig ud for at være Esau, og udstyrer ham med gamle blinde Isaks livret og gedeskind på de hårløse arme. Isak tror, at Jakob er Esau, og således lykkes det Jakob at stjæle deres døende fars velsignelse, ligesom han stjæler førstefødselsretten i vores fortælling om linserne.

Men hvad står der egentlig i Første Mosebog 25 om linserne? Der står, at Jakob koger en stuvning eller gryderet (nazijd), der består af linser ('adāšijm), og har en rød eller rødbrun farve ('âdom). Det udlægges ofte som et tegn på, at Jakobs linser var røde linser (MacDonald 2008, 26).

Her bør man naturligvis være opmærksom på, at stuvningens røde farve i 1 Mos 25,30 først og fremmest tjener et ikke-kulinarisk formål. Esau bliver nemlig stamfader til folket Edom ('ādom, 'rød', 1 Mos 36), og denne forbindelse trækker forfatteren til Første Mosebog på igen og igen i fortællingen om Jakob og Esau. Da Esau bliver født, 
er han fx dækket af røde hår over hele kroppen, og da denne behårede vildmand sælger sin førstefødselsret uden at blinke, er det for en skål rød stuvning.

Esau spiser stuvningen med brød til, og får også noget at drikke, men vi får ikke at vide, hvad han drikker. Jakobs stuvning bliver ofte tolket som en vegetarret, formodentlig på grund af kontrasten mellem den blodtørstige jæger, Esau, og den vel nærmest blodfattige hyrde, Jakob; men det er faktisk ikke noget, der fremgår eksplicit af teksten (Shafer-Elliott 2013, 153-155).

De fleste formidlende bibelkogebøger bringer en relativt simpel opskrift på linsesuppe kogt på røde linser i forlængelse af fortællingen om Jakob og Esau i 1 Mos 25 (Lehman-Wilzig 2003, 21-23; Vamosh 2004, 94; Rossner 2013, 24-27). Men der er også eksempler på mere frie fortolkninger af samme fortælling, som vi så det i Kitty Morses oksekødssuppe med linser, sennepsblade og perlebyg ovenfor, og i Chiffolo og Hesses Cooking with the Bible, hvor linse-historien foldes ud til en hel menu, der består af brød, linser med ris, en form for tzaziki, stuvede løg fyldt med linser, nødder og frugt, en lammestuvning, bagt gedeost med urter, tørrede abrikoser, pistacienødder og til sidst den spektakulære chokoladekage, der kaldes rød fløjlskage ("red velvet cake") til ære for ordspillet på rød/Edom (2006, 11-20).

\subsection{Saras brød}

I fortællingen om Abraham og Saras gæster i 1 Mos 18 beskrives måltidet en anelse mere udførligt:

\footnotetext{
Abraham skyndte sig ind i teltet til Sara og sagde: “Tag hurtigt tre sea fint mel, ælt det, og bag brød." Selv løb Abraham ud til kvæget og tog en god og fin kalv; den gav han til karlen, som skyndte sig at tilberede den. Derpå tog han tykmælk og mælk og den kalv, som var blevet tilberedt, og satte det for dem. Selv stod han hos dem, mens de sad og spiste under træet (1 Mos 18,6-8).
}

Måltidet består af tre komponenter, brød ('ugot), en kalv (bæn bāqār) og mælkeprodukter (ḥæmāh og hâāāb). Den hebraiske glose, 'ugot, er en form for fladbrød eller pandekage, der enten bages på indersiden af en muret ovn, en tabun, eller på en varm sten, der anbringes i ildstedet. Tre sea mel svarer til 24 liter, så det er en forsvarlig portion, der er tale om. Det fremgår af vers 6, at måltidet skal tilberedes så hurtigt som muligt, så det kan være, at Saras brød er såkaldt usyrede brød, dvs. tilberedt uden hævning for at spare tid (Shafer-Elliott 2013, 143-145). Det fine mel er formodentlig omhyggeligt sigtet hvedemel, som blev anset for at være mere fornemt end bygmel, den anden meget almindelige kornsort i oldtiden (MacDonald 2008, 19-21).

Kalven er et festmåltid, og langt mere fornem og kostbar end fx et får eller en ged. Den mest almindelige måde at tilberede kød på i oldtidens Palæstina har været at skære det i mindre stykker og koge det i en gryde. Helstegning, som vi fx ser det $\mathrm{i}$ forbindelse med påskemåltidet i 2 Mos 12, hørte til sjældenhederne (Lundager Jensen 2004a, 31-35; Shafer-Elliott 2013, 145-146; Gudme 2015, 28-30).

Mælkeprodukterne, hæmāh og hāläb, der i DO-1992 oversættes med “tykmælk og mælk" kan betyde friske mælkeprodukter, formodentlig lavet af gedemælk, men der kan også være tale om forarbejdede mælkeprodukter, der kan holde længere, såsom 
tørret friskost og klaret smør eller ghee (Gudme 2012; MacDonald 2008, 35-36). Abraham og Saras gæster bliver altså budt på et fornemt og rigeligt måltid, der består af en kalvestuvning, fladbrød og to slags mælkeprodukter.

Måltidet i 1 Mos 18 bliver i de formidlende bibelkogebøger brugt som inspiration til opskrifter på alt fra yoghurt (Morse 2009, 81), og 'Saras brød' (Vamosh 2004, 90), over pitabrød med salat og hummus (Lehmann-Wilzig 2003, 17-19) til et omfattende måltid, bestående af bygbrød, suppe, grøntsagsstuvning, kamelmælk med safran, friskost med dadler, grillspyd med kalvekød og grøntsager og en 'engle-kage' (Chiffolo og Hesse 2009, 1-9).

Andre populære bibelhistorier i de formidlende bibelkogebøger er påskemåltidet i 2 Mos 12, Abigajils beværtning af kong David i 1 Sam 25, dronning Esters gentagne drikkegilder i Esters Bog, de mirakuløse bespisninger med brød og fisk i fx Mark 6,3044 og 8,1-10 og naturligvis beretningerne om den sidste nadver.

\subsection{Bibelske genskrivninger og kendiskogebøger}

De formidlende bibelkogebøger lader sig altså til en vis grad guide og inspirere af Bibelen, når det kommer til valg af køkken, ingredienser og opskrifter, men de associerer også frit på baggrund af bibelteksterne, og lader sig sjældent begrænse af teksternes kortfattethed eller af en ambition om historisk korrekthed. Det forekommer mig, at de formidlende bibelkogebøger i virkeligheden er en kombination af to genrer. Den ene er kendiskogebogen, som man også kunne kalde for kogebogslitteraturens fanfiktion. Den anden er den type litteratur, der kaldes bibelske genskrivninger.

Bibelske genskrivninger er en forskelligartet type af tekster, der bygger videre på Bibelens litterære univers og persongalleri (Høgenhaven \& Müller, eds, 2012; Damgaard \& Gudme, eds. 2009). Opdelingen mellem bibelske tekster og bibelske genskrivninger er med rette blevet kritiseret for at være kunstig, fordi den bygger på skellet mellem kanoniske og ikke-kanoniske tekster, et skel, der først blev sat relativt sent i disse teksters tilblivelseshistorie (Holst 2012). Ikke desto mindre kan betegnelsen bibelske genskrivninger hjælpe os til at beskrive det fænomen, at der i de sidste århundreder før og de første århundreder efter vor tidsregning var en hyppig produktion af tekster, der synes at tage udgangspunkt i tilsyneladende allerede kendte bibelfortællinger og at genskrive disse fortællinger i en eller anden form. Genskrivningerne kan være et forsøg på at udfylde huller eller råde bod på uklarheder i fortællingerne, men de kan også have karakter af mere håndfaste forsøg på omskrivning af eksisterende tekster (Poulsen 2012). Det er et tilbagevendende træk ved bibelske genskrivninger, at genskrivningen fortæller videre på historien, hvor den genfortalte tekst slipper op eller bliver tavs. Det kan man fx se eksempler på i tekster som Josef og Asenat og Abrahams Testamente, der fortæller videre på vigtige begivenheder i bibelske hovedpersoners liv, i disse tilfælde Josefs ægteskab med egypterinden Asenat og patriarken Abrahams død (Plum, Christiansen \& Otzen 2009). Denne tendens til at ville fortælle videre og til at få fortælleuniverset til at vare ved minder en hel del om det moderne fænomen fanfiktion, hvor læsere skriver videre på populære bøger og film, såsom Ringenes Herre, Harry Potter og Twilight (Larsen 2010). 
Fanfiktionen danner bro til den anden genre, som den formidlende bibelkogebog er beslægtet med, nemlig kendiskogebogen. En kendiskogebog er i al sin enkelhed en kogebog, der er skrevet af en eller flere kendte personer. I modsætning til kogebøger skrevet af kendte kokke, såsom Paul Bocuse (1983), Auguste Escoffier (2011, først udgivet på dansk i 1927) med mange flere, er kendiskogebogen typisk skrevet af eller tilskrevet en person, der er kendt for noget andet end at lave mad. Et klassisk eksempel er Elvis Presley kogebogen, Are You Hungry Tonight (Butler 1999), der først blev oversat til dansk i 1999, og som gav Kongens fans mulighed for at genskabe deres idols livretter. Andre eksempler er Barbara og Frank Sinatras Celebrity Cookbook og Sophia Lorens Recipes \& Memories. I en dansk kontekst har DRs madprogrammer Spice med Price genoplivet interessen for deres far, skuespilleren, instruktøren og madelskeren John Prices kogebog af samme navn (Nyvang og Leer 2016), og danske kogebogslæsere kan også komme i køkkenet med 'Baronessen' alias Caroline Fleming (2009) og lave mad med komikeren Timm Vladimir (2013). Kendiskogebogen er et udtryk for idoldyrkelse. Man kommer tættere på stjernerne, hvis man ved, hvad de spiser, eller spiser det samme som dem. Her bør man dog nok hæfte sig ved, at kogebøger før som nu sjældent afspejler den mad, der faktisk spises, men snarere den mad man godt kunne tænke sig, man spiste (Nyvang 2014).

En videreudvikling af kendiskogebogen er kogebøger, der er baseret på populære bøger, film eller tv-serier. Tove Janssons mumitrolde har givet inspiration til en kogebog, og det samme har A.A. Milnes Peter Plys. Ligeledes har tv-serierne The Sopranos, Friends, True Blood og Game of Thrones resulteret i kogebogsudgivelser. Man skulle umiddelbart tro, at det er et relativt nyt fænomen; men allerede i 1939 kunne man købe en kogebog inspireret af det storladne Hollywood-drama Borte med blæsten, der havde premiere samme år. Disse kogebøger digter videre på et elsket fortælleunivers i opskriftsform, og har således karakter af genskrivning og fanfiktion.

Den formidlende bibelkogebog er altså en kogebog, der genskriver og fortæller videre på de bibelske fortællinger, og knytter madopskrifter til disse fortællinger, sådan at læseren kan lave mad og spise 'sammen med' de bibelske hovedpersoner. Den formidlende bibelkogebog formidler bibelhistorier; men den bruger også opskriften som en vej for læseren til at komme ind i og blive en del af Bibelens litterære univers. Der ligger en dobbelthed i, at mad og opskrifter på den ene side er sensuelt, aktualiserende og vedkommende, og at kogebøger på den anden side oftere bruges til at bladre i end til at lave mad efter. Ikke desto mindre vil jeg hævde, at den formidlende bibelkogebog både giver læseren en indgang til bibelteksten i form af mad og sanseindtryk (selv hvis maden aldrig når fra papiret til tallerkenen), og samtidig formidler bibelfortællinger i opskriftsform.

\section{Hvad ville Jesus spise? Den etiske bibelkogebog}

Den etiske bibelkogebog bruger Bibelen til at komme med et bud på, hvordan og hvad man bør spise. I modsætning til den formidlende bibelkogebog, der primært synes at ville oplyse og underholde, har den etiske bibelkogebog et præskriptivt sigte. Den 
etiske bibelkogebog har til hensigt at få læseren til at adoptere en bestemt måde at spise på, en diæt, der er i overensstemmelse med Bibelen, der i denne kontekst forstås som Guds ord og udtryk for Guds vilje.

Et godt eksempel på en etisk bibelkogebog er lægen og forfatteren Don Colberts The What Would Jesus Eat? Cook Book (2002). Colberts bibelkogebog har det til fælles med den formidlende bibelkogebog, at han ikke forsøger at skrive en historisk kogebog. Bogen er i bund og grund en samling af lettilgængelige moderne opskrifter fra middelhavskøkkenet, og til sammenligning med langt de fleste formidlende bibelkogebøger trækker Colbert stort set ikke på tekster fra Bibelen. Filosofien bag The What Would Jesus Eat? Cook Book er at man ved at spise som Jesus kan leve i overensstemmelse med Guds vilje:

If you truly want to follow Jesus in every area of your life, you cannot ignore your eating habits. It is an area in which you can follow Him daily and reap great rewards for doing so. Following Jesus in your diet requires a commitment to change, a commitment to be all that God created you to be, and a commitment to yield your desires to God's instruction. God, in turn, will honor heartfelt commitment by giving you more energy, better health, and a greater sense of well being. Are you willing to make a commitment to follow Jesus' example and eat the way He ate? If you are, then let's begin cooking (Colbert 2002, ix).

Det Nye Testamente har ikke megen information om, hvad og hvordan Jesus og disciplene spiste. I Matt 15,11.17-20 siger Jesus, at det ikke er det, der kommer ind i munden, der gør et menneske urent, men snarere det, der kommer ud af munden. Denne replik læses ofte som et forsøg på at gøre op med de spise- og renhedsregler, der kan læses i 3 Mos 11. Jesus bliver omtalt som en "frådser og dranker “ i Matt 11,1819 (jf. Luk 7,34), og i fortællingen om brylluppet i Kana i Joh 2 lader det til, at han drikker vin. Samtidig står der i Matt 4,2, at Jesus fastede fyrre dage i ørkenen. De nytestamentlige tekster er lige præcis så forskelligartede og kortfattede, når det kommer til Jesus' forhold til mad, at de kan udlægges til at understøtte hvad som helst. På baggrund af Det Nye Testamente bliver Jesus fremstillet både som afholdsmand og dranker, vegetar og kødspiser og som asket og ædedolk. Konklusionen afhænger i høj grad af, hvilket forbillede fortolkeren er på udkig efter (Horrell 2008; Hartman 2010).

Det Nye Testamentes kortfattethed giver ligeledes Colbert masser af manøvrerum. Han sammenfatter en Jesuslignende diæt som kost, der har et højt næringsindhold, der ikke er industrielt fremstillet, men som består af friske råvarer, og som desuden skal spises i ro og mag og i selskab med venner og familie (2002, vii-ix). Han konkluderer i øvrigt på et ukendt grundlag, at Jesus kun spiste ganske lidt kød, og at Jesus spiste mange grøntsager (2002, 91. 146; Armelagos 2004).

\subsection{Hvad ville Noah spise? En kreationistisk bibelkogebog}

Et andet eksempel på en etisk bibelkogebog er Gary F. Zeollas Creationist Diet: Nutrition and God-Given Foods According to the Bible (2000). Som titlen antyder, er Zeollas bibelkogebog et kristent-kreationistisk modsvar til den palæodiæt, der har vundet 
indpas siden 1990erne (Armelagos 2004). Tanken bag palæobølgen er, at det er sundest for mennesker at spise 'naturligt' og dermed at spise, som vore forfædre i ældre stenalder, palæolitikum, gjorde det (Jensen 2012). Det kan meget vel være rigtigt, skriver Zeolla, hvis man altså tror på evolutionsteori; men det gør han ikke, og derfor vil han komme med et bud på en kreationistisk diæt, baseret på skabelsesberetningerne og urhistorien i Det Gamle Testamente (1 Mos 1-11). Zeolla udlægger Bibelen på baggrund af et princip om, at jo tættere vi kommer på skabelsen, desto mere oprindeligt og dermed rigtigt er et givent vilkår eller påbud. På bagrund af dette princip skelner Zeolla mellem Gudgiven mad og ikke-Gudgiven mad, og når således frem til en række anbefalinger til en kreationistisk diæt, der er i overensstemmelse med Guds vilje (2000, xiii-xv og 101-114).

Læseren skal ikke snydes for disse anbefalinger. Men først er det på sin plads med et kort referat af de mad-relaterede passager i 1 Mos $1-11 .^{2}$ Det første nedslag er 1 Mos 1,29-30, Gud giver de nyligt skabte mennesker de grønne planter og frugttræerne til mad. På baggrund af disse vers kan det udledes, at kosten i Edens have er vegetarisk og vildtvoksende.

Dette forhold ændrer sig, da Adam og Eva forvises fra Eden i 1 Mos 3. Menneskets ændrede livsvilkår efter 'faldet' omfatter nu at dyrke agerjorden i sit ansigts sved og at kæmpe mod tjørn og tidsler for at få jorden til at bære frugt (1 Mos 3,17-19). Uden for Edens have er kosten stadig vegetarisk, men ikke længere vild og frit tilgængelig.

Den næste ændring i menuen indtræffer efter syndfloden, hvor Gud beslutter sig for at udvide den oprindelige vegetariske diæt i 1 Mos 1,29-30 og tillade, at der spises kød:

Hos alle de vilde dyr, hos alle himlens fugle, hos alle krybdyr på jorden og hos alle havets fisk skal der være frygt og rædsel for jer; de er givet i jeres magt. Alt, hvad der rører sig og lever, skal I have til føde. Jeg giver jer det alt sammen, ligesom jeg gav jer de grønne planter (1 Mos 9,3).

Herefter går der lang tid, før Det Gamle Testamente igen ytrer sig om, hvad man må og ikke må spise. Vi skal helt frem til 3 Mos 11, hvor vi finder de klassiske gammeltestamentlige spiseregler, der forbyder svinekød og skaldyr og såmænd også klippegrævlinger, ørne m.m.

Historien om babelstårnet i 1 Mos 11,1-9 nævner ikke et ord om mad; men den er vigtig for Zeolla, fordi den markerer overgangen fra urhistorien til patriarkfortællingerne og 'resten' af det Gamle Testamente. Frem til historien om babelstårnet handler fortællingen i Det Gamle Testamente om hele menneskeheden og har et universelt præg, hvorimod fortællingen efter Babel snævres ind til i første omgang at handle om én familie og $i$ anden omgang denne families efterkommere i form af det udvalgte folk, Israel. Således kan Zeolla supplere sit tæt-på-skabelsen princip med et før-eller-

2 Zeollas alimentære læsning af urhistorien (1 Mos 1-11) afviger ikke fra akademisk-eksegetisk fornuft på dette punkt, selvom han i modsætning til flertallet af forskere ikke skelner mellem 1 Mos 1, der ifølge kildesondringshypotesen regnes for at høre til den præstelige redaktion, og 1 Mos 2-3, der ifølge samme hypotese tilskrives Jahvisten. For en kort introduktion til kildesondringshypotesen, se Gudme m.fl. 2016, 13-16. For alimentære-eksegetiske læsninger af 1 Mos 1-3 og 6-9, se Lundager Jensen 2004 [2000], 129-135 og 159-164, og Rogerson 2010. 
efter-Babel princip, hvor kostråd, der optræder før 1 Mos 11, tillægges større vægt end kostråd, der kommer efter 1 Mos 11 (2000, 61-62).

På baggrund af en læsning af 1 Mos 1-11 og med enkelte perspektiveringer til resten af Det Gamle Testamente skitserer Zeolla således fire bibelske diæter: (1) The Edenic Diet, der består af grønne planter, nødder og frø ('raw food'); (2) The Antediluvian Diet, der består af raw food, korn og bælgfrugter; (3) The Noahic Diet, der består af raw food, korn, bælgfrugter og kød, og (4) The Promised Land Diet, der består af raw food, korn, bælgfrugter, kød, mælk og honning, og afspejler en fortællesituation, hvor folket Israel er blevet fastboende i det forjættede land, Kanaan (2000, 101). Zeollas liste over Gudgiven mad omfatter frugt, grøntsager, nødder, frø, korn, bælgfrugter, kød fra 'rene' dyr og fisk (jf. 3 Mos 11), vegetabilsk olie, honning og mælkeprodukter. Ikke-Gudgiven mad er derimod industrielt fremstillede eller kraftigt forarbejdede kornprodukter og sukker, kød fra 'urene' dyr (jf. 3 Mos 11), præfabrikerede kødprodukter, æg, margarine og dybstegt mad (2000, 103-106).

Zeolla ender ikke med klart at anbefale én kreationistisk kostplan frem for de andre; men han synes dog at hælde til den antediluviske diæt, fordi den er sund, og fordi Noas forfædre i 1 Mos 5 alle bliver meget gamle (2000, 27-28).

The Creationist Diet er ikke en kogebog i klassisk forstand. Den indeholder kun ganske få opskrifter; men den er et eksempel på en ernæringshåndbog, der anbefaler, at man omlægger sin kost på baggrund af og i overensstemmelse med Bibelen.

\subsection{Præsten \& Kogejomfruen: En etisk og formidlende kogebog skrevet af Herrens kokke}

Afslutningsvis vil jeg nævne en af de få bibelkogebøger, der er udgivet på dansk, Poul Joachim Stender og Susanne Engelstoft Rasmussens Præsten \& Kogejomfruen (2003). I min indledning nævnte jeg, at Præsten \& Kogejomfruen både er formidlende og etisk, og med det mener jeg, at den både har en ambition om at formidle bibelhistorier ved hjælp af mad og opskrifter, samtidig med at den har et etisk og præskriptivt sigte, der går ud på at få sanseligheden ind i kirken og at gøre oprør imod det forfatterne kalder den protestantiske etiks krav om kontrol (2003, 11-12). Forfatterne er med deres egne ord "på mission for Gud"; de er "Guds kokke", og de vil "lægge himlen ned i maden eller løfte maden op til himlen" og "sprede glæde og fællesskab i Jesu navn" (18. 258259).

Præsten og kogejomfruen er skrevet specifikt til dansk madkultur og til det danske kirkeår, og derfor indeholder den opskrifter til fx Helligtrekongersaften (s. 96-99), Fastelavn (s. 110-114) og Sankthans (s. 194-197); men den har også mere klassiske bibelkogebogsindslag, som fx en opskrift på "fedekalv, som Abraham og den fortabte søn ville have værdsat" (s. 190).

\section{Med Gud i køkkenet: Bibelkogebogen som bibelreception}

Der er stor variation blandt bibelkogebøger, de kan være mere eller mindre 'bibelske', de kan være mere eller mindre kogebogsagtige, og som jeg har forsøgt at demonstrere i denne artikel, kan de være enten overvejende formidlende, overvejende etiske eller 
en blanding af de to. Til trods for denne forskelligartethed kan man dog alligevel sige noget generelt om bibelkogebogen som bibelreception.

Bibelkogebøger udlægger og genfortæller Bibelen med henblik på at omsætte bibelteksten til konkrete opskrifter eller kostråd. Den formidlende bibelkogebog har en ambition om at oplyse om Bibelen og at formidle bibelfortællinger og Bibelens univers ved hjælp af mad og opskrifter. Heroverfor har den etiske bibelkogebog i langt højere grad en adfærdsregulerende ambition, den ønsker ikke kun at oplyse eller at underholde, men at hjælpe læseren til at følge Guds vilje ved at spise i overensstemmelse med Bibelen. De tre eksempler på etiske bibelkogebøger, Colberts The What Would Jesus Eat? Cook Book, Zoellas The Creationist Diet og Stender og Rasmussens Præsten $\mathcal{E}$ Kogejomfruen, demonstrerede, at Guds vilje med hensyn til hvad man bør spise, kan udlægges meget forskelligt, og at en gudvelbehagelig kostplan både kan være at spise som Noa, at spise som Jesus og at spise med alle sanser og med stor fornøjelse.

De formidlende og de etiske bibelkogebøger har det til fælles, at Bibelens kortfattethed om mad og køkken skaber vide rammer for fortolkningen. Bibelkogebøgerne henter inspiration og autoritet i Bibelen; men de lader sig ikke begrænse af ambitioner om historisk korrekthed. Bibelkogebogen omsætter Bibelen til opskrifter i en form, der passer til samtidens behov, interesser og ambitionsniveau, og på den måde lægger den sig fint i forlængelse af genren bibelske genskrivninger, der fortæller videre på Bibelen med henblik på at aktualisere den i en ny kontekst. Men bibelkogebogen kan også andet og mere end at genfortælle bibelhistorier. Den kan vise os al den mad, vi godt kunne tænke os at lave, hvis vi en dag skulle med Gud i køkkenet.

\section{LITTERATUR}

Armelagos, George

2004 "Evolutionists and Creationists at the Dinner Table", Evolutionary Anthropology 13 (2), 53-55. https://doi.org/10.1002/evan.10129

Bocuse, Paul

1983 Bocuse i Deres køkken, Arnold Busck.

Butler, Brenda Arlene

1999 Are You Hungry Tonight? Elvis Presley kogebogen, Askholm.

Chiffolo, Anthony F. og Rayner W. Hesse, Jr.

2009 Cooking with the Bible: Recipes for Biblical Meals, Greenwood Press.

Damgaard, Finn \& Anne Katrine de Hemmer Gudme, eds.

2009 Bibelske genskrivninger, Bibliana 1.

Det Danske Bibelselskab

2005 Smag på Bibelen, www.bibelselskabet.dk (set 16. maj 2018).

Escoffier, Auguste

2011 Escoffiers store kogebog, Nyt Nordisk Forlag.

Fleming, Caroline

2009 Baronessen går i køkkenet, Lindhardt og Ringhof.

Gudme, Anne Katrine de Hemmer

2012 “Er oversætterne løbet sur i teksten?”, Spørg om Bibelen: http://www.bibelselskabet.dk/_(set 16. 
maj 2018).

2015 "Med Døden til bords: Gæstfrihed og kvinder i Det Gamle Testamente", in: Finn Damgaard \& Anne Katrine de Hemmer Gudme, eds., Mad og drikke i bibelsk litteratur, Forum for Bibelsk Eksegese 19. FBE i samarbejde med Eksistensen Akademisk, 26-53. http://teol.ku.dk/abe/ publikationer/forum_for_bibelsk_eksegese (set 16. maj 2018).

Gudme, Anne Katrine de Hemmer et al.

2016 "Indledning: Fire indgange til gammeltestamentlig teologi", in: Gudme et al, eds., Fire indgange til gammeltestamentlig teologi, Det Teologiske Fakultet: Københavns Universitet, 7-25.

Hartman, Laura M

2010 "Consuming Christ: The Role of Jesus in Christian Food Ethics", Journal of the Society of Christian Ethics 30 (1), 45-62.

Holst, Søren

2012 "Hvornår er en tekst bibelsk? Bearbejdede Mosebøger blandt Dødehavsrullerne", in: Jesper Høgenhaven \& Mogens Müller, eds., Bibelske genskrivninger, , Forum for Bibelsk Eksegese 17. Museum Tusculanums Forlag, 111-138. http://teol.ku.dk/abe/publikationer/ forum_for_bibelsk_eksegese/fbe17-bibelske-genskrivninger/FBE17SoerenHolst6.pdf_set 16. maj 2018).

Horrell, David G.

2008 "Biblical Vegetarianism? A Critical and Constructive Assessment", in: David Grumett \& Rachel Muers, eds., Eating and Believing, Continuum International Publishing, 44-59. https://doi.org/10.5040/9780567678140-ch-003

Høgenhaven, Jesper \& Mogens Müller, eds.

2012 Bibelske genskrioninger. Forum for Bibelsk Eksegese 17. Museum Tusculanums Forlag. http://teol.ku.dk/abe/publikationer/forum_for_bibelsk_eksegese/fbe17-bibelske-genskrivninger/ (set 16. maj 2018).

Jensen, Tania Lousdal

2012 "Stenalderjægerne guffede gerne kulhydrater", Indlæg på Videnskab.dk, https://videnskab.dk/kultur-samfund/stenalderjaegerne-guffede-gerne-kulhydrater (set 16. maj 2018).

Larsen, Kasper Bro

2010 "Bibelske fortællinger som fanfiktion", Religionspædagogisk Forum 1, 64-72. http://www. eksistensen.dk/media/wysiwyg/Tidsskrifter/Religionspaedagogisk_Forum/.

Lehmann-Wilzig, Tami

2003 Tasty Bible Stories: A Menu of Tales and Matching Recipes, Kar-Ben Publishing.

2008 What did the Ancient Israelites Eat? Diet in Biblical Times. Wm. B. Eerdmans Publishing Co.

Lundager Jensen, Hans J.

2004a "Ritualer i kontekst: ritualerne for påske, måltidsoffer og forsoningsdagen i Det Gamle Testamente", in: Mette Birkedal Bruun \& Kim Esmark, eds., Ritualer i kontekst, Kirkehistoriske fragmenter 2, Det Teologiske Fakultet: København, 25-41.

2004b Den fortærende ild: Strukturelle analyser af narrative og rituelle tekster i Det Gamle Testamente, 2. udgave [1. udgave: 2000], Aarhus Universitetsforlag.

Morse, Kitty

2009 A Biblical Feast: Ancient Mediterranean Flavors for Today's Table, La Caravane.

Musselman, Lytton John

2011 A Dictionary of Bible Plants, Cambridge University Press. https://doi.org/10.1017/CBO9781139035323

Nyvang, Caroline

2014 "I den gode smags tjeneste. Den gastronomiske bølge i danske kogebøger 1950-73", Tidsskrift for Kulturforskning 12 (3-4), 64-81.

Nyvang, Caroline \& Jonatan Leer

2016 "Spise reprise: Historiebrug i Brdr. Prices madprogrammer", Kulturstudier 2016 (1), 143-158. 
Plum, Karin Friis, Jørgen Ledet Christiansen \& Benedikt Otzen

2009 Tre jødiske legender, Anis.

Poulsen, Frederik

2012 "Eksodusbegivenheden i Deuterojesaja: Genskrivning eller overskrivning?", in: Jesper

Høgenhaven og Mogens Müller 2012, 89-109. http://teol.ku.dk/abe/publikationer

/forum_for_bibelsk_eksegese/fbe17-bibelske-genskrivninger/_(set 16. maj 2018).

Rogerson, John W.

2010 "The Creation Stories: Their Ecological Potential and Problems", in: Horrell et al., eds., Ecological Hermeneutics: Biblical, Historical and Theological Perspectives, T\&T Clark, 21-31.

Rossner, Rena

2013 Eating the Bible: Over 50 Delicious Recipes to Feed Your Body and Nourish Your Soul, Skyhorse

Publishing.

Stender, Poul Joachim \& Susanne Engelstoft Rasmussen

2003 Præsten E Kogejomfruen, Unitas.

Vamosh, Miriam Feinberg

2004 Food at the Time of the Bible: From Adam's Apple to the Last Supper, Abingdon Press.

Vladimir, Timm

2013 Timm Vladimirs køkken, Lindhardt og Ringhof.

Anne Katrine de Hemmer Gudme, Professor MSO, ph.d. Afdeling for Bibelsk Eksegese, Det Teologiske Fakultet, Københavns Universitet

akg@teol.ku.dk 